\title{
How do learning orientation and strategy yield innovativeness and superior firm performance?
}

\author{
M. Dülger*, G. Alpay, C. Yılmaz and M. Bodur \\ Author 1, 2 and 4: Boğaziçi University, Faculty of Economics and Administrative Sciences, \\ Department of Management, 34342 Bebek Istanbul TURKEY \\ meraldulger@gmail.com
}

Author 3 : Middle East Technical University, Faculty of Economics and Administrative Sciences, Department of Management 06800 Cankaya Ankara TURKEY

\begin{abstract}
This paper attempts to shed light on the role of learning orientations of firms and their adoption of Porter's generic strategies on four dependent variables: Behavioral innovativeness, product innovativeness, technological innovativeness and, ultimately, firm performance. Hierarchical regressions were run with data from a random sample of 121 firms operating in Turkey. Findings indicate that internally-focused learning, market-focused learning and differentiation strategy have significant effects on the three innovativeness dimensions. When firm performance is included as the eventual outcome variable into the analysis, internally-focused learning, focus strategy and product innovativeness emerge as its main predictors. In fast-paced, highly unpredictable market environments, managers can make use of these findings to their benefit in terms of elevating their firms' innovativeness and performance levels.
\end{abstract}

Keywords: innovativeness, learning orientation, strategy, Porter, performance, Turkey

*To whom all correspondence should be addressed.

\section{Introduction}

The $21^{\text {st }}$ century has proved itself to be an era of uncertainty, heightened competition, complex environmental dynamics and constant change which leaves firms with the sole option of innovativeness (Hult, Hurkey \& Knight, 2004; Wang \& Ahmed, 2004; Blumentritt \& Danis, 2006; Hsu, 2007; Lin, Peng \& Kao, 2008; Man \& Wafa, 2009; Rhee, Taekyung \& Lee, 2010). Hence, firms should extend ways to learn more about their customers, stakeholders, competitors and the marketplace if they are to survive by higher levels of innovativeness. Moreover, these activities must be consistent with an overarching organizational strategy where elevating levels of innovativeness must take the center stage in order to boost firm performance. Thus, this study seeks to discover the relationships of learning orientation, strategic choice with firm performance and the role of dimensions of innovativeness as full or partial mediators.

On top of this, as an underrated country in emerging market research, Turkey actually provides a unique setting by being the $15^{\text {th }}$ biggest economy of the world with its GDP of over 773 billion dollars (World Bank, 2012). Also, it is the first and only country that entered Customs Union of the European Union (EU) in 1996 without becoming a full member. Therefore, fierce competition from developed and emerging markets comes in. Currently, firms face the need to become innovative for overcoming the defects in the domestic marketplace whilst addressing the competition and customer needs. Dynamic ways to compete appeared whereas lags occurred in other aspects and consequently, we find the responses of Turkish firms noteworthy. A comprehensive model tests a representative sample of domestic and multinational business to consumer (B2C) firms.

\section{Model development}

\section{Conceptual model}

Research on innovativeness/innovations in developed markets tends to focus on R\&D while our model is based on firm-level activities. For emerging economies, Pietrobelli and Rebellotti (2011) underline three points to consider in drawing conclusions about innovation activities: First, most innovation is based on non-R\&D activities which consist of operationalizing technology that is new to the situation of application (Bell, 2007); second, universities, R\&D laboratories and/or research institutes may be inadequate and linkages among them and with local firms may be weak or nonexistent; third, especially international inflows of knowledge and technology from external sources are vital factors of the innovation and learning processes.

As this conceptual model aims to find out about how firms manage to learn about and adapt to the free market conditions and competition, we emphasize the multidimensionality of the constructs. Adhering to Wang and Ahmed's (2004) research, five innovativeness dimensions will be employed as propellers of organizational 
performance along with three dimensions of organizational learning (Weerawardena, O'Cass \& Julian, 2006) and Porter's (1980) three generic strategic positioning types. The model in Figure 1 proposes that each dimension of innovativeness may influence firm performance through various learning orientations and strategies of firms.

The general research question is whether organizational learning and Porter's (1980) generic strategic positioning types are predictors of organizational innovativeness and ultimately firm performance. In particular, whereas the sequence of effects from organizational learning to innovativeness and firm performance are well-established in prior research, how strategic choice interplays within this framework is the main research issue. In addition, due to lack of prior evidence, whether the mediating role of innovativeness is full or partial and how this role differs across dimensions of learning orientation and strategic choice remains as another exploratory question. Further, we investigate the effects of organizational age, industry, organizational size, and export income as control variables.

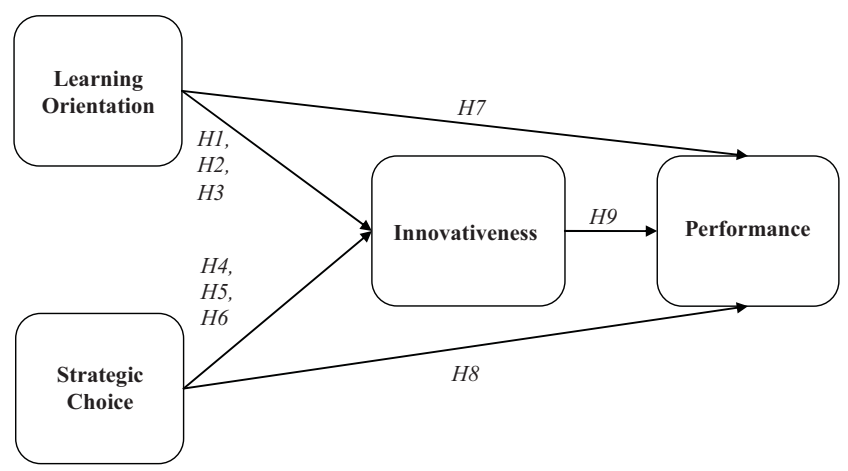

Figure 1: Conceptual model

\section{Turkey as an emerging market}

To establish the macro setting, we provide common features of emerging markets with respect to Turkey. Such markets supply valuable case studies and natural laboratories in the context of global integration (Danis, Chiaburu \& Lyles, 2010). Emerging markets are characterized by low-income, rapid-growth and having economic liberalization as the key driver for development (Hoskisson, Eden, Lau \& Wright, 2000). Competition is promoted domestically, supporting local firms to cultivate international levels of competitiveness (Aulakh \& Kotabe, 2008). The early years of transition are characterized by economic decline, social upheaval and political uncertainty resulting in a highly ambiguous environment (Danis et al., 2010) while the competitive landscape stabilizes as ongoing economic and institutional reforms take hold (Warner \& Cornelius, 2002). Emerging markets have different ways of processing market information and thus, the resulting strategies quite different than the ones in mature economies (Bruton, Dess \& Janney, 2007: 118). In addition, the efficacy of organizational processes may be contingent upon the economic context in which firms compete (Li, Zhang, Liu \& Li, 2010: 64).
The Turkish the market was liberalized in 1984 but it struggled with high inflation, coalition governments, instable economy and corruption. However, since 2003, the one-party government generated stability and forseeability through sustainable reforms: GDP increased from 232 billion dollars in 2002 to over 773 billion dollars in 2012, inflation fell from $45 \%$ in 2002 to $6.4 \%$ in 2012 and total reserves increased to almost 88 billion dollars in 2012 from 28 billion dollars in 2002 (World Bank, 2012).

\section{Hypotheses}

\section{Innovativeness and learning orientation}

Even if a particular organization has room for innovative ideas to flourish, generating tangible innovations might take a long time, there might be resistance or managers might lack adequate interest. Hence, as a construct, we chose innovativeness and we are interested in how it is affected under diminished market stability and predictability as these may jeopardize the ultimate realization of innovations.

Academic research usually approaches innovativeness as a measure of the degree of "newness" of an innovation (Garcia \& Calantone, 2002). As innovativeness requires new information and knowledge so that new ideas can flourish, the aptitude to learn more rapidly than competitors may be the only sustainable competitive advantage in volatile environments (Slater \& Narver, 1995). Hence, the learning orientations of firms emerge as an area of interest. Rhee et al. (2010) define learning orientation as the adoption of a basic learning process. Besides, the association between innovativeness with learning orientation is verified by numerous researchers (Baker \& Sinkula, 1999; 2002; Calantone, Cavusgil \& Zhao et al., 2002; Hult et al., 2004; Lin et al., 2008; Rhee et al., 2010).

Wang and Ahmed (2004) identify five main areas that establish an organization's overall level of innovativeness which are product, market, process, behavioral and strategic innovativeness: Product innovativeness emphasizes the novelty and meaningfulness of products while market innovativeness points out to the originality of approaches that firms adopt to penetrate and take advantage of their targeted markets. Process innovativeness captures the introduction of new production methods, management approaches and technology to advance production and management processes. Behavioral innovativeness aids the configuration of an innovative culture. Lastly, strategic innovation is the aptitude to manage ambitious organizational purposes and existing resources so that it is able to leverage limited resources productively.

Weerawardena et al. (2006) identify three types of learning orientations: market focused learning, relationally focused learning and internally-focused learning. They describe market focused learning as the capacity of the firm to acquire, disseminate, unlearn and use market information for organizational change. Such activities are beneficial in the speed and effectiveness of responses to environmental 
opportunities and threats. Thus, to realize higher levels of innovativeness, firms need to relentlessly scan, evaluate, reflect on and learn about their environments:

H1: Higher levels of market-focused learning will generate higher (a) product innovativeness, (b) market innovativeness, (c) process innovativeness, (d) behavioral innovativeness, (e) strategic innovativeness.

Internally focused learning is the capacity and extent a firm develops knowledge through internal sources (Weerawardena et al., 2006). It includes learning by practice, tentative learning along with in-house R\&D and is crucial for attaining new knowledge. So, we propose that technical knowledge is a noteworthy source in stimulating novel and superior ideas:

H2: Higher levels of internally-focused learning will generate higher (a) product innovativeness, (b) market innovativeness, (c) process innovativeness, (d) behavioral innovativeness, (e) strategic innovativeness.

Firms also learn from other firms and external research institutions, such as universities and industry associations and the capacity and extent an organization acquires knowledge through external linkages or networks describe relationally focused learning (Weerawardena et al., 2006). Consequently, we posit that for prompting novel ideas, firms need to have relations that provide quality knowledge:

H3: Higher levels of relationally-focused learning will generate higher (a) product innovativeness, (b) market innovativeness, (c) process innovativeness, (d) behavioral innovativeness, (e) strategic innovativeness.

\section{Innovativeness and strategic choice}

Grant (2008:17) describes strategy as "a means by which individuals or organizations achieve their objectives". This means can certainly be about organized learning activities that will give way to innovations that ultimately result in enhanced firm performance. However, the environmental unpredictability and dynamism interact with organizations in ways which one might not encounter in mature markets. Thus, the rapid political, economic and institutional change along with rather immature factor and product markets (Wright, Filatotchev, Hoskisson \& Peng, 2005) provide an interesting setting to explore strategic choice in relation to innovativeness.

A firm can gain competitive advantage by generating value for customers by performing strategically significant endeavors either cheaply or better than competitors do (Porter, 1980). These activities are known as generic strategies and Porter (1980) classifies them as cost leadership, differentiation and focus. Thompson Jr., Strickland III and Gamble (2005) explain these strategies as follows: Cost leadership involves finding ways to drive costs out of a given business and trying to have the lower overall costs than competition. Differentiation strategies are attractive whenever buyers' requirements and preferences are too varied to be completely fulfilled by a standardized product. Thus, this strategy entails becoming unique in ways that are valuable to a broad range of customers. Focus strategy involves concentrating on a narrow piece of the total market which is also known as niche and has two variants: cost focus and differentiation focus. Cost focus entails serving buyers in the target niche at a lower cost and lower prices than competitors whereas differentiation focus entails offering a product that niche members perceive as well suited to their own unique tastes and preferences.

Here, we would like to investigate the nature of this association and reveal how different choices of Porter's (1980) generic strategies affect different dimensions of innovativeness. Even though there are a number of academic undertakings, we find that this topic is under-researched. For example, although Man and Wafa (2008) investigate Porter's (1980) generic strategies for only small and medium sized enterprises (SMEs) whereas our sample includes MNCs and larger-sized firms. We found a similar conceptualization in Blumentritt and Danis' (2006) study and even if they use Miles and Snow's (1978) typology, they conclude that a firm's innovation efforts must fit with its strategic efforts. As innovation derives from innovativeness, we deem that integrating strategic choice with innovativeness perspectives is reasonable. Further, there is a similar model in the study of Ferraresi, Quandt, Dos Santos and Frega (2012) in terms of relating strategic orientation to innovativeness. However, the study does not employ Porter's (1980) generic strategies. Even more, none of the studies referred here has examined these constructs in relation to organizational learning. Still, we consider Freeman's (1978: 255) note that any classification of strategies is rather arbitrary and violates the vast range of conditions in the real world. Accordingly, due to the small amount of findings in the literature, we propose these relatively general hypotheses:

H4: There is a positive relationship between cost leadership strategy and (a) product innovativeness, (b) market innovativeness, (c) process innovativeness, (d) behavioral innovativeness, (e) strategic innovativeness.

H5: $\quad$ There is a positive relationship between differentiation strategy and (a) product innovativeness, (b) market innovativeness, (c) process innovativeness, (d) behavioral innovativeness, (e) strategic innovativeness.

H6: There is a positive relationship between focus strategy and (a) product innovativeness, (b) market innovativeness, (c) process innovativeness, (d) behavioral innovativeness, (e) strategic innovativeness.

\section{Effects on performance}

As for the relation between learning orientation and organizational performance, the literature provides academic evidence (Baker \& Sinkula, 1999; Lei, Slocum \& Pitts, 
1999; Calantone et al., 2002; Hanvanich, Sivakumar \& Hult, 2006; Frank, Kessler, Mitterer \& Weismeier-Sammer, 2012). Organizational learning is priceless in terms of providing better insight about customers and efficiently meeting their requirements and needs through new products, services and ways of doing business (Slater \& Narver, 1995). Firms that learn about customers, competitors and regulators have superior odds of perceiving and acting upon incidents and tendencies in the market and this leads directly to greater new product success, superior customer retention, higher customer-defined quality, and, ultimately superior growth and/or profitability (López, Peón \& Ordés, 2005). We consequently suggest that:

H7: Higher levels of (a) market focused learning; (b) internally focused learning and (c) relationally focused learning will generate greater organizational performance.

About the relationship between strategic choice and organizational performance, the most recognized account is Porter's (1985), where he reveals a significant relationship between the strategy types and the firm performance. Furthermore, Miller and Friesen (1986), Miller (1986), White (1986) and Yamin, Gunasekaran and Mavondo's (1999) studies are well-known. Further, Man and Wafa (2008) come to the same conclusion in their study although they consider only export performance as an indicator of firm performance. Hence:

H8: There is a positive relationship between (a) cost strategy, (b) differentiation strategy, (c) focus strategy and organizational performance.

Finally, we observed that recent research has revealed that innovativeness is associated with business performance (Cooper, 2000; Calantone et al., 2002, Hult et al., 2004). Hult et al. (2004) assert that, to respond to the turbulent milieu, it is vital to fuel innovativeness, which is critical for achieving high performance. Thus, we propose that:

H9: Higher levels of (a) product innovativeness, (b) market innovativeness, (c) process innovativeness, (d) behavioral innovativeness, and (e) strategic innovativeness will generate greater organizational performance.

\section{Method}

\section{Sample and data collection}

The sampling enclosed available membership lists of chambers of commerce of major trading cities in Turkey such as İstanbul, İzmir, Ankara, Kocaeli, and Adana. Executives of 700 randomly chosen firms were contacted via telephone and/or e-mail, and as a result and $121 \mathrm{~B} 2 \mathrm{C}$ firms agreed to participate in the study. One respondent from each firm answered structured questionnaires through face-to-face interviews. The complete questionnaire can be found in the appendix.
Respondents were on average 40,5 years old with a standard deviation of 9,8 and have an average organizational tenure of 9,1 years with a standard deviation of 7,3. Eighty seven percent of the respondents are male, 9,1 percent are primary, middle school and high school graduates, 52,1 percent hold university undergraduate degrees, and 38,8 percent hold post-graduate degrees. Ninety one percent of the respondents are middle and top managers, while 8,2 percent are specialists, experts, and consultants. The firms are from a wide variety of industries, including textiles and clothing, financial services, consumer durables, construction services, tourism, food and other FMCG, logistics, transport and warehousing, automotive, and other services and manufacturing firms. Overall, 51,3 percent of the firms are in manufacturing and 48,7 percent are in services industries. Firm ages range from 2 to 221 years with a mean of 24,5 years and a standard deviation of 24,4 years. Firm size ranges from 16 to 174.000 employees with a mean of 2706,2 and a standard deviation of 16209,2 . Forty nine percent of the firms do not have any export income, 42 percent retain up to 50 percent of their income from exports and 9 percent retain 51 to 100 percent of their income from exports.

\section{Measures}

The questionnaire was constructed using the measures that are explained in the next paragraph. Each measure has multiple-items with 5-point summated rating scales with anchors of 1 being strongly disagree and 5 being strongly agree, except for firm and respondent demographics. For each construct, we ran exploratory factor analyses with varimax rotation and averaged the mean scores of each dimension separately.

To measure innovativeness, Wang and Ahmed's (2004) 29item scale was utilized. 13 items were eliminated and the reliability estimate is 0,87 which is above the threshold levels suggested by Nunnally (1978). Market-focused learning $(\alpha=0,76)$ was measured via the 8 -item scale developed by Weerawardena (2003), internally-focused learning $(\alpha=0,92)$ was measured via an 8 -item scale of an adapted version of measures developed by Atuahene-Gima (1993) and relationally-focused learning $(\alpha=0,66)$ was measured via 8-items developed by Cohen and Levinthal (1990) and Rothwell (1992). To measure strategic choice, a literature review including Miller and Friesen (1986); Bush and Sinclair (1992); Yamin et al. (1999); Panayides (2003); Powers and Hahn (2004) and Allen and Helms (2006) yielded a pool of items. The purification process generated a total of 22 items. 7 items accounted for cost leadership strategy $(\alpha=0,69), 10$ for differentiation strategy $(\alpha=0,66)$ and 5 relating to focus strategy $(\alpha=0,73)$. To measure firm performance $(\alpha=0,70)$, respondents were asked to indicate their firms' level of performance for the last 3 years of operations on return on investment, market share, and total sales growth (e.g., Baker \& Sinkula, 2009). We also included a judgmental assessment of overall performance as in the study of Jaworski and Kohli (1993). All four performance items use five-point scales with anchors 1 being much worse than competition and 5 being much better 
than competition. The rationale for using a three-year performance is that changing market conditions, developments in technology and crises may easily lead firms to make sure they achieve short term goals.

\section{Table 1: Final measures and psychometric properties}

\begin{tabular}{|c|c|c|}
\hline Measures* & Factor Loading & Cronbach's Alpha \\
\hline Organizational Innovativeness & & 0,87 \\
\hline Product Innovativeness & & 0,86 \\
\hline In new product and service introductions, our firm is often first-to-market. & 0,80 & \\
\hline Our new products and services are often perceived as very novel by customers. & 0,81 & \\
\hline $\begin{array}{l}\text { In comparison with our competitors, our firm has introduced more innovative products and services in during } \\
\text { the past five years }\end{array}$ & 0,81 & \\
\hline In comparison with our competitors, our firm is faster in bringing new products or services into the market. & 0,81 & \\
\hline $\begin{array}{l}\text { In comparison with our competitors, our products most recent marketing program is revolutionary in the } \\
\text { market. }\end{array}$ & 0,68 & \\
\hline Behavioral Innovativeness & & 0,86 \\
\hline We are constantly improving our business processes. & 0,57 & \\
\hline We get a lot of support from managers if we want to try new ways of doing things. & 0,81 & \\
\hline Key executives of the firm are willing to take risks to seize and explore "chancy" growth opportunities. & 0,59 & \\
\hline Senior executives constantly seek unusual, novel solutions to problems via the use of "idea men". & 0,69 & \\
\hline In our firm, we tolerate individuals who do things in a different way. & 0,78 & \\
\hline We are willing to try new ways of doing things and seek unusual, novel solutions. & 0,81 & \\
\hline We encourage people to think and behave in original and novel ways. & 0,80 & \\
\hline Technological Innovativeness & & 0,81 \\
\hline In new product and service introductions, our firm is often at the cutting edge of technology. & 0,69 & \\
\hline The technology of our main machinery in use is very up-to-date. & 0,77 & \\
\hline Our future investments in new machinery and equipment are significant compared with our annual turnover. & $0, .85$ & \\
\hline Our future investments in new methods of production are significant compared with our annual turnover. & 0,73 & \\
\hline Learning Orientation & & 0,89 \\
\hline Market-focused Learning & & 0,76 \\
\hline We collect information about markets. & 0,82 & \\
\hline We search for innovative ideas through market information. & 0,73 & \\
\hline We have knowledge about market segments. & 0,78 & \\
\hline Relationally-focused Learning & & 0,66 \\
\hline We use customer and competitor information in innovations. & 0,70 & \\
\hline We review past unsuccessful endeavors. & 0,66 & \\
\hline We use knowledge generated externally in innovations. & 0,74 & \\
\hline We review past unsuccessful programs for external knowledge. & 0,61 & \\
\hline Internally-focused Learning & & 0,92 \\
\hline We undertake internal R\&D. & 0,82 & \\
\hline We internally share knowledge generated through internal R\&D. & 0,79 & \\
\hline We review past unsuccessful R\&D. & 0,76 & \\
\hline The skill level of staff involved in R\&D is high. & 0,85 & \\
\hline We allocate a considerable amount to R\&D. & 0,64 & \\
\hline Our R\&D knowledge is used in innovations. & 0,86 & \\
\hline We have capacity to acquire knowledge through $\mathrm{R} \& \mathrm{D}$ & 0,82 & \\
\hline Strategic Choice & & 0,61 \\
\hline Cost Leadership & & 0,69 \\
\hline We have strict cost controls for every business activity. & 0,78 & \\
\hline We minimize costs of waster, repair, etc. & 0,72 & \\
\hline In our firm, we have frequent preparation of detailed control reports. & 0,81 & \\
\hline Differentiation & & 0,66 \\
\hline We base our incentives on meeting quality improvement goals. & 0,59 & \\
\hline We allow the personnel to test and we tolerate them to fail. & 0,82 & \\
\hline We evaluate the cost of failures not as a loss but as an opportunity to learn. & 0,84 & \\
\hline Focus & & 0,73 \\
\hline $\begin{array}{l}\text { We serve limited number of customers belonging to specific segments rather than competing with rivals in the } \\
\text { full market. }\end{array}$ & 0,75 & \\
\hline We target the niche market rather than the large market. & 0,91 & \\
\hline We undertake extensive market research in a specific niche market. & 0,74 & \\
\hline Firm Performance & & 0,70 \\
\hline Total sales growth & 0,61 & \\
\hline Market share & 0,68 & \\
\hline Return on investments & 0,59 & \\
\hline Total sales growth & 0,82 & \\
\hline
\end{tabular}

Items for all measures and reliability estimates for the multiple item measures are exhibited in Table 1.

\section{Organizational Innovativeness}

In new product and service introductions, our firm is often first-to-market.

Our new products and services are often perceived as very novel by customers.

the past five years

In comparison with our competitors, our firm is faster in bringing new products or services into the market.

In comparison with our competitors, our products most recent marketing program is revolutionary in the

We are constantly improving our business processes.

We get a lot of support from managers if we want to try new ways of doing things.

We are willing to try new ways of doing things and seek unusual, novel solutions.

We encourage people to think and behave in original and novel ways.

The technology of our main machinery in use is very up-to-date.

Our future investments in new machinery and equipment are significant compared with our annual turnover.

(a) significant compared with our annual turnover.

\section{Market-focused Learning}

We collect information about markets.

We search for innovative ideas through market information.

Relationally-focused Learning

We use customer and competitor information in innovations.

We use knowledge generated externally in innovations.

We review past unsuccessful programs for external knowledge.

Internally-focused Learning

We review past unsuccessful $R \& D$.

The skill level of staff involved in R\&D is hig

We allocate a considerable amount to $\mathrm{R} \& \mathrm{D}$.

Our R\&D knowledge is used in innovations.

We have capacity to acquire knowledge through R\&D

\section{Cost Leadership}

Differentiation

We evaluate the cost of failures not as a loss but as an opportunity to learn.

Focus

full market.

We target the niche market rather than the large market.

We undertake extensive market research in a specific niche market.

Total sales growth

Return on investments

Notes:

* Factor analyses are run separately for items in the innovativeness measures. Innovativeness and performance items are analyzed together 


\section{Results}

The descriptive statistics and the bivariate correlations across the constructs are exhibited in Table 2 to provide a general depiction of the relationships of interest.

Table 2: Pearson correlation results

\begin{tabular}{|c|c|c|c|c|c|c|c|c|c|c|c|}
\hline Pearson Correlation & Mean & SD & 1 & 2 & 3 & 4 & 5 & 6 & 7 & 8 & 9 \\
\hline $\begin{array}{l}\text { Performance Indicators } \\
\text { (1) }\end{array}$ & 3,8854 & 0,57604 & & & & & & & & & \\
\hline $\begin{array}{l}\text { Internally-Focused } \\
\text { Learning (2) }\end{array}$ & 3,7485 & 0,91492 & $0,466 * *$ & & & & & & & & \\
\hline $\begin{array}{l}\text { Market-Focused } \\
\text { Learning (3) }\end{array}$ & 4,3416 & 0,56020 & $0,346^{* *}$ & $0,498 * *$ & & & & & & & \\
\hline $\begin{array}{l}\text { Relationally-Focused } \\
\text { Learning (4) }\end{array}$ & 3,9215 & 0,60038 & $0,257^{*}$ & $0,417 * *$ & $0,355^{* *}$ & & & & & & \\
\hline $\begin{array}{l}\text { Cost Leadership } \\
\text { Strategy (5) }\end{array}$ & 3,9646 & 0,64357 & 0,093 & $0,230^{*}$ & $0,351 * *$ & $0,268^{*}$ & & & & & \\
\hline $\begin{array}{l}\text { Differentiation Strategy } \\
\text { (6) }\end{array}$ & 3,7686 & 0,73263 & $0,330 * *$ & $0,487 * *$ & $0,345^{* *}$ & $0,460 * *$ & $0,216^{*}$ & & & & \\
\hline Focus Strategy (7) & 3,0579 & 1,01167 & $-0,159^{*}$ & $0,159^{*}$ & 0,110 & 0,097 & 0,120 & $-0,028 * *$ & & & \\
\hline $\begin{array}{l}\text { Behavioral } \\
\text { Innovativeness (8) }\end{array}$ & 3,8253 & 0,66764 & $0,286^{* *}$ & $0,429 * *$ & $0,425 * *$ & $0,490 * *$ & $0,201 *$ & $0,657 * *$ & 0,050 & & \\
\hline $\begin{array}{l}\text { Product Innovativeness } \\
\text { (9) }\end{array}$ & 3,5233 & 0,87895 & $0,494 * *$ & $0,478 * *$ & $0,413 * *$ & $0,245^{*}$ & 0,131 & $0,304 * *$ & 0,014 & $0,362 * *$ & \\
\hline $\begin{array}{l}\text { Technological } \\
\text { Innovativeness (10) }\end{array}$ & 3,6346 & 0,89692 & $0,293 * *$ & $0,561 * *$ & $0,341 * *$ & $0,344 * *$ & $0,292 * *$ & $0,313 * *$ & 0,116 & $0,351^{* *}$ & $0,382 * *$ \\
\hline${ }^{*} \mathbf{p}<0,05 ;{ }^{* *} \mathbf{p}<0,01$ & & & & & & & & & & & \\
\hline
\end{tabular}

To test the hypotheses, we employed 4 hierarchic regression models with SPSS 19 so that we could see each construct's contribution to each model one by one. Specifically, we entered the control variables as the first set of independents, followed by learning orientation dimensions and the strategic choice variables. One of the three innovativeness dimensions was the dependent variable for the first three regression analyses to test $\mathrm{H} 1$ - H6. We ran the fourth regression analysis where firm performance was the dependent variable to test $\mathrm{H} 7$ - H9. The outcomes of these analyses are depicted in Table 3 to 6 .
In the first model, learning orientation and strategic choice dimensions were analyzed as predictors of behavioral innovativeness. As Table 3 shows, the control variables explain only 5,4 percent of the variability in behavioral innovativeness, which is not statistically significant $\left(\mathrm{F}_{(4 ; 109)}\right.$ $=1,548)$. The inclusion of learning orientation dimensions increases the explained variance in a statistically and substantively significant sense $\left(\Delta \mathrm{R}^{2}=0,344 ; \Delta \mathrm{F}_{(3 ; 106)}=\right.$ 20,158; $\mathrm{p}<0,01)$. Also, the strategic choice dimensions provide an incremental increase in variance explained which is statistically significant $\left(\Delta \mathrm{R}^{2}=0,186 ; \Delta \mathrm{F}_{(3 ; 103)}=15,278 ; \mathrm{p}\right.$ $<0,01$ ). 
Table 3: Regression results for behavioral innovativeness

\begin{tabular}{|c|c|c|c|c|c|c|c|c|c|}
\hline & \multicolumn{3}{|c|}{ Model 1} & \multicolumn{3}{|c|}{ Model 2} & \multicolumn{3}{|c|}{ Model 3} \\
\hline & $\begin{array}{l}\text { Regression } \\
\text { Coefficient }\end{array}$ & $\begin{array}{l}\text { Standard } \\
\text { Error }\end{array}$ & $\begin{array}{c}\text { Std. } \\
\text { Coefficient }\end{array}$ & $\begin{array}{l}\text { Regression } \\
\text { Coefficient }\end{array}$ & $\begin{array}{l}\text { Standard } \\
\text { Error }\end{array}$ & $\begin{array}{c}\text { Std. } \\
\text { Coefficient }\end{array}$ & $\begin{array}{l}\text { Regression } \\
\text { Coefficient }\end{array}$ & $\begin{array}{l}\text { Standard } \\
\text { Error }\end{array}$ & $\begin{array}{c}\text { Std. } \\
\text { Coefficient }\end{array}$ \\
\hline \multicolumn{10}{|l|}{ Control Variables } \\
\hline Organizational Age & $-0,005$ & 0,003 & $-0,195 * *$ & $-0,004$ & 0,002 & $-0,147^{*}$ & $-0,004$ & 0,002 & $-0,143 * *$ \\
\hline Industry & 0,003 & 0,139 & 0,002 & $-0,194$ & 0,117 & $-0,146$ & $-0,265$ & 0,100 & $-0,199 * * *$ \\
\hline Organizational Size & 0,000 & 0,000 & $-0,067$ & 0,000 & 0,000 & $-0,090$ & 0,000 & 0,000 & $-0,064$ \\
\hline Export Income & $-0,002$ & 0,003 & $-0,059$ & $-0,001$ & 0,002 & $-0,027$ & $-0,001$ & 0,002 & $-0,054$ \\
\hline \multicolumn{10}{|l|}{$\begin{array}{l}\text { Independent } \\
\text { Variables }\end{array}$} \\
\hline \multicolumn{10}{|l|}{$\begin{array}{l}\text { Learning } \\
\text { Orientation } \\
\text { Dimensions }\end{array}$} \\
\hline $\begin{array}{l}\text { Internally-focused } \\
\text { Learning }\end{array}$ & & & & 0,194 & 0,070 & $0,266^{* *}$ & 0,083 & 0,063 & 0,113 \\
\hline $\begin{array}{l}\text { Market-focused } \\
\text { Learning }\end{array}$ & & & & 0,283 & 0,108 & $0,238^{* *}$ & 0,212 & 0,094 & $0,178^{* *}$ \\
\hline $\begin{array}{l}\text { Relationally- } \\
\text { focused Learning }\end{array}$ & & & & 0,295 & 0,098 & $0,265 * * *$ & 0,116 & 0,088 & 0,104 \\
\hline \multicolumn{10}{|l|}{$\begin{array}{l}\text { Strategic Choice } \\
\text { Dimensions }\end{array}$} \\
\hline $\begin{array}{l}\text { Cost Leadership } \\
\text { Strategy }\end{array}$ & & & & & & & 0,043 & 0,063 & 0,048 \\
\hline Focus Strategy & & & & & & & 0,002 & 0,044 & 0,003 \\
\hline $\begin{array}{l}\text { Differentiation } \\
\text { Strategy }\end{array}$ & & & & & & & 0,479 & 0,072 & $0,526^{* * *}$ \\
\hline \multicolumn{10}{|l|}{ Model Summary } \\
\hline Adjusted R Square & 0,019 & & & 0,358 & & & 0,543 & & \\
\hline R Square & 0,054 & & & 0,397 & & & 0,583 & & \\
\hline$\Delta$ in R Square & 0,054 & & & 0,344 & & & 0,186 & & \\
\hline F for $\Delta$ in $R$ Square & 1,548 & & & $20,158^{* * *}$ & & & $15,278 * * *$ & & \\
\hline F for $A N O V A$ & 1,548 & & & $9,990 * * *$ & & & $14,402 * * *$ & & \\
\hline $\begin{array}{l}* p<0,10 \\
* * p<0,05 \\
* * * p<0,01\end{array}$ & & & & & & & & & \\
\hline
\end{tabular}

Note: Provided in the Table are the results of three sequential regression runs. Model 1 regresses Behavioral Innovativeness against the control variables only, and the following models include learning orientation dimensions, and strategic choice dimensions one after the other hierarchically.

Concerning the individual effects of learning orientation dimensions (Table 3, Model 2), internally-focused learning $\left(\beta_{\mathrm{i}}=0,266 ; \mathrm{p}<0,05\right)$ exerts the highest positive impact on behavioral innovativeness, followed by relationally-focused learning $\left(\beta_{\mathrm{i}}=0,265 ; \mathrm{p}<0,01\right)$ and market-focused learning $\left(\beta_{\mathrm{i}}=0,238 ; \mathrm{p}<0,05\right)$. Finally, for learning orientation dimensions and strategic choice dimensions (Table 3, Model $3)$, industry $\left(\beta_{\mathrm{i}}=-0,199 ; \mathrm{p}<0,01\right)$ possesses the highest negative impact on behavioral innovativeness followed by firm age $\left(\beta_{i}=-0,143 ; p<0,05\right)$ meaning that behavioral innovativeness tends to be higher in younger service firms. As for significant and positive relationships, market-focused learning $\left(\beta_{\mathrm{i}}=0,178 ; \mathrm{p}<0,05\right)$ and to differentiation strategy $\left(\beta_{\mathrm{i}}=0,526 ; \mathrm{p}<0,01\right)$ explain behavioral innovativeness.
In the second model, learning orientation and strategic choice dimensions were analyzed as predictors of product innovativeness. As Table 4 exhibits, the control variables explain only 2 percent of the variability in product innovativeness, which is statistically non-significant $\left(\mathrm{F}_{(4 ; 109)}\right.$ $=0,545)$. With the addition of learning orientation dimensions, the explained variance explained increases in a statistically and substantively significant sense $\left(\Delta \mathrm{R}^{2}=\right.$ 0,$\left.257 ; \Delta \mathrm{F}_{(3 ; 106)}=12,538 ; \mathrm{p}<0,01\right)$. The incremental variance explained through including strategic choice dimensions is not statistically significant $\left(\Delta \mathrm{R}^{2}=0,012\right.$; $\left.\Delta \mathrm{F}_{(3 ; 103)}=0,569\right)$. 
Table 4: Regression results for product innovativeness

\begin{tabular}{|c|c|c|c|c|c|c|c|c|c|}
\hline & \multicolumn{3}{|c|}{ Model 1} & \multicolumn{3}{|c|}{ Model 2} & \multicolumn{3}{|c|}{ Model 3} \\
\hline & $\begin{array}{l}\text { Regression } \\
\text { Coefficient }\end{array}$ & $\begin{array}{l}\text { Standard } \\
\text { Error }\end{array}$ & $\begin{array}{c}\text { Std. } \\
\text { Coefficient }\end{array}$ & $\begin{array}{l}\text { Regression } \\
\text { Coefficient }\end{array}$ & $\begin{array}{l}\text { Standard } \\
\text { Error }\end{array}$ & $\begin{array}{c}\text { Std. } \\
\text { Coefficient }\end{array}$ & $\begin{array}{l}\text { Regression } \\
\text { Coefficient }\end{array}$ & $\begin{array}{l}\text { Standard } \\
\text { Error }\end{array}$ & $\begin{array}{c}\text { Std. } \\
\text { Coefficient }\end{array}$ \\
\hline \multicolumn{10}{|l|}{ Control Variables } \\
\hline Organizational Age & 0,001 & 0,004 & 0,023 & 0,001 & 0,003 & 0,040 & 0,002 & 0,003 & 0,043 \\
\hline Industry & 0,176 & 0,186 & 0,101 & $-0,096$ & 0,169 & $-0,055$ & $-0,109$ & 0,172 & $-0,062$ \\
\hline Organizational Size & 0,000 & 0,000 & 0,081 & 0,000 & 0,000 & 0,018 & 0,000 & 0,000 & 0,028 \\
\hline Export Income & $-0,002$ & 0,004 & $-0,068$ & $-0,001$ & 0,003 & $-0,041$ & $-0,001$ & 0,003 & $-0,039$ \\
\hline \multicolumn{10}{|l|}{$\begin{array}{l}\text { Independent } \\
\text { Variables }\end{array}$} \\
\hline \multicolumn{10}{|l|}{$\begin{array}{l}\text { Learning } \\
\text { Orientation } \\
\text { Dimensions }\end{array}$} \\
\hline $\begin{array}{l}\text { Internally-focused } \\
\text { Learning }\end{array}$ & & & & 0,362 & 0,101 & $0,377 * * *$ & 0,348 & 0,108 & $0,362 * *$ \\
\hline $\begin{array}{l}\text { Market-focused } \\
\text { Learning }\end{array}$ & & & & 0,341 & 0,156 & $0,217 * *$ & 0,353 & 0,161 & $0,225^{*}$ \\
\hline $\begin{array}{l}\text { Relationally- } \\
\text { focused Learning }\end{array}$ & & & & 0,036 & 0,142 & 0,025 & 0,025 & 0,152 & 0,017 \\
\hline \multicolumn{10}{|l|}{$\begin{array}{l}\text { Strategic Choice } \\
\text { Dimensions }\end{array}$} \\
\hline $\begin{array}{l}\text { Cost Leadership } \\
\text { Strategy }\end{array}$ & & & & & & & $-0,060$ & 0,108 & $-0,052$ \\
\hline Focus Strategy & & & & & & & $-0,060$ & 0,075 & $-0,069$ \\
\hline $\begin{array}{l}\text { Differentiation } \\
\text { Strategy }\end{array}$ & & & & & & & 0,085 & 0,124 & 0,071 \\
\hline \multicolumn{10}{|l|}{ Model Summary } \\
\hline Adjusted R Square & $-0,016$ & & & 0,229 & & & 0,219 & & \\
\hline R Square & 0,020 & & & 0,276 & & & 0,288 & & \\
\hline$\Delta$ in $R$ Square & 0,020 & & & 0,257 & & & 0,012 & & \\
\hline$F$ for $\Delta$ in $R$ Square & 0,545 & & & $12,538 * * *$ & & & 0,569 & & \\
\hline$F$ for $A N O V A$ & 0,545 & & & $5,748 * * *$ & & & $4,170 * * *$ & & \\
\hline $\begin{array}{l}* \mathbf{p}<\mathbf{0 , 1 0} \\
* * \mathbf{p}<0,05 \\
* * * \mathbf{p}<0,01\end{array}$ & & & & & & & & & \\
\hline
\end{tabular}

Note: Provided in the Table are the results of three sequential regression runs. Model 1 regresses Product Innovativeness against the control variables only, and the following models include learning orientation dimensions, and strategic choice dimensions one after the other hierarchically.

As for the individual effects of learning orientation dimensions (Table 4, Model 2), internally-focused learning $\left(\beta_{\mathrm{i}}=0,377 ; \mathrm{p}<0,01\right)$ followed by market-focused learning $\left(\beta_{\mathrm{i}}=0,217 ; \mathrm{p}<0,05\right)$ exert the highest positive impact on product innovativeness. In terms of learning orientation dimensions and strategic choice dimensions (Table 4, Model $3)$, only internally-focused learning $\left(\beta_{\mathrm{i}}=0,362 ; \mathrm{p}<0,01\right)$ and market-focused learning $\left(\beta_{\mathrm{i}}=0,225 ; \mathrm{p}<0,10\right)$ are statistically significant and positively related to product innovativeness. This denotes that an increase in internallyfocused and market-focused learning will reflect itself in amplified product innovativeness.
In the third model, learning orientation and strategic choice dimensions were analyzed as predictors of technological innovativeness. As Table 5 exhibits, the control variables are statistically significant $\left(\mathrm{F}_{(4 ; 107)}=3,024\right)$ and explain 10 percent of the variability in technological innovativeness. Adding the learning orientation dimensions into the analysis increases explained variance in a statistically and substantively significant sense $\left(\Delta \mathrm{R}^{2}=0,275 ; \Delta \mathrm{F}_{(3 ; 104)}=\right.$ $15,298 ; \mathrm{p}<0,01)$. However, incremental variance explained by including the strategic choice dimensions into the analysis is not statistically significant $\left(\Delta \mathrm{R}^{2}=0,016 ; \Delta \mathrm{F}_{(3 ; 101)}\right.$ $=0,880)$. 
Table 5: Regression results for technological innovativeness

\begin{tabular}{|c|c|c|c|c|c|c|c|c|c|}
\hline & \multicolumn{3}{|c|}{ Model 1} & \multicolumn{3}{|c|}{ Model 2} & \multicolumn{3}{|c|}{ Model 3} \\
\hline & $\begin{array}{l}\text { Regression } \\
\text { Coefficient }\end{array}$ & $\begin{array}{l}\text { Standard } \\
\text { Error } \\
\end{array}$ & $\begin{array}{c}\text { Std. } \\
\text { Coefficient }\end{array}$ & $\begin{array}{l}\text { Regression } \\
\text { Coefficient }\end{array}$ & $\begin{array}{l}\text { Standard } \\
\text { Error } \\
\end{array}$ & $\begin{array}{c}\text { Std. } \\
\text { Coefficient }\end{array}$ & $\begin{array}{l}\text { Regression } \\
\text { Coefficient }\end{array}$ & $\begin{array}{l}\text { Standard } \\
\text { Error }\end{array}$ & $\begin{array}{c}\text { Std. } \\
\text { Coefficient }\end{array}$ \\
\hline \multicolumn{10}{|l|}{ Control Variables } \\
\hline Organizational Age & $-0,008$ & 0,004 & $-0,226 * *$ & $-0,007$ & 0,003 & $-0,197 * *$ & $-0,007$ & 0,003 & $-0,194 * *$ \\
\hline Industry & 0,421 & 0,184 & $0,236^{* *}$ & 0,142 & 0,162 & 0,079 & 0,121 & 0,164 & 0,068 \\
\hline Organizational Size & 0,000 & 0,000 & 0,045 & 0,000 & 0,000 & $-0,008$ & 0,000 & 0,000 & $-0,031$ \\
\hline Export Income & 0,002 & 0,004 & 0,051 & 0,002 & 0,003 & 0,056 & 0,001 & 0,003 & 0,038 \\
\hline \multicolumn{10}{|l|}{$\begin{array}{l}\text { Independent } \\
\text { Variables } \\
\end{array}$} \\
\hline \multicolumn{10}{|l|}{$\begin{array}{l}\text { Learning } \\
\text { Orientation } \\
\text { Dimensions } \\
\end{array}$} \\
\hline $\begin{array}{l}\text { Internally-focused } \\
\text { Learning }\end{array}$ & & & & 0,453 & 0,097 & $0,462 * * *$ & 0,001 & 0,103 & $0,476^{* * *}$ \\
\hline $\begin{array}{l}\text { Market-focused } \\
\text { Learning }\end{array}$ & & & & 0,135 & 0,149 & 0,084 & 0,087 & 0,153 & 0,054 \\
\hline $\begin{array}{l}\text { Relationally- } \\
\text { focused Learning }\end{array}$ & & & & 0,123 & 0,136 & 0,082 & 0,087 & 0,144 & 0,058 \\
\hline \multicolumn{10}{|l|}{$\begin{array}{l}\text { Strategic Choice } \\
\text { Dimensions }\end{array}$} \\
\hline $\begin{array}{l}\text { Cost Leadership } \\
\text { Strategy }\end{array}$ & & & & & & & 0,157 & 0,103 & 0,132 \\
\hline Focus Strategy & & & & & & & 0,022 & 0,072 & 0,024 \\
\hline $\begin{array}{l}\text { Differentiation } \\
\text { Strategy }\end{array}$ & & & & & & & $-0,019$ & 0,118 & $-0,016$ \\
\hline \multicolumn{10}{|l|}{ Model Summary } \\
\hline Adjusted R Square & 0,068 & & & 0,335 & & & 0,332 & & \\
\hline R Square & 0,102 & & & 0,377 & & & 0,393 & & \\
\hline$\Delta$ in $R$ Square & 0,102 & & & 0,275 & & & 0,016 & & \\
\hline F for $\Delta$ in $R$ Square & $3,024 * *$ & & & $15,298^{* * *}$ & & & 0,880 & & \\
\hline F for $A N O V A$ & $3,024 * *$ & & & $8,977 * * *$ & & & $6,526^{* * *}$ & & \\
\hline $\begin{array}{l}{ }^{*} \mathbf{p}<\mathbf{0 , 1 0} \\
* * p<0,05 \\
* * * p<0,01\end{array}$ & & & & & & & & & \\
\hline
\end{tabular}

Note: Provided in the Table are the results of three sequential regression runs. Model 1 regresses Technological Innovativeness against the control variables only, and the following models include learning orientation dimensions, and strategic choice dimensions one after the other hierarchically.

About the individual effects of learning orientation dimensions (Table 5, Model 2), only internally-focused learning $\left(\beta_{\mathrm{i}}=0,462 ; \mathrm{p}<0,01\right)$ has the highest positive impact on technological innovativeness. Organizational age $\left(\beta_{\mathrm{i}}=-0,197 ; \mathrm{p}<0,05\right)$ is negatively related to technological innovativeness depicting that younger firms tend to have higher levels of technological innovativeness. Regarding the effects of firm characteristics, learning orientation dimensions and strategic choice dimensions (Table 5, Model $3)$, organizational age $\left(\beta_{\mathrm{i}}=-0,194 ; \mathrm{p}<0,05\right)$ exerts the highest negative impact on technological innovativeness meaning that as organizational age decreases technological innovativeness increases. Lastly, only internally-focused learning $\left(\beta_{\mathrm{i}}=0,476 ; \mathrm{p}<0,01\right)$ positively and significantly explains technological innovativeness.

Finally, in the fourth model, learning orientation, strategic choice and innovativeness dimensions were analyzed as predictors of ultimate firm performance. As Table 6 depicts, the control variables explain only 5,3 percent of the variability in firm performance, which is not statistically significant $\left(\mathrm{F}_{(4 ; 107)}=1,488\right)$. In this analysis, only industry significantly affects firm performance, pointing out that, firm performance is better in service firms than in production firms. After the addition of learning orientation dimensions into the analysis in the second model, the proportion of variance explained increases in a statistically and substantively significant sense $\left(\Delta \mathrm{R}^{2}=0,210 ; \Delta \mathrm{F}_{(3 ; 104)}=\right.$ 9,888; $\mathrm{p}<0,01)$. Similarly, strategic choice dimensions significantly increase the variance explained in firm performance $\left(\Delta \mathrm{R}^{2}=0,069 ; \Delta \mathrm{F}_{(3 ; 101)}=3,462 ; \mathrm{p}<0,05\right)$. Lastly, after the inclusion of innovativeness dimensions, the incremental variance explained is significant $\left(\Delta \mathrm{R}^{2}=0,064\right.$; $\left.\Delta \mathrm{F}_{(3 ; 98)}=3,476 ; \mathrm{p}<0,05\right)$. 
Table 6: Regression results for firm performance

\begin{tabular}{|c|c|c|c|c|c|c|c|c|c|c|c|c|}
\hline & \multicolumn{3}{|c|}{ Model 1} & \multicolumn{3}{|c|}{ Model 2} & \multicolumn{3}{|c|}{ Model 3} & \multicolumn{3}{|c|}{ Model 4} \\
\hline & 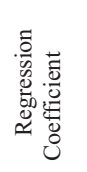 & 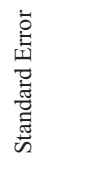 & 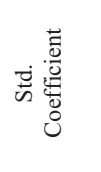 & 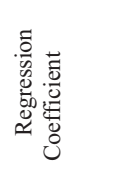 & 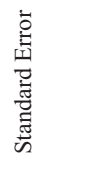 & $\vec{D} \frac{\overrightarrow{0}}{\stackrel{\overrightarrow{0}}{0}}$ & 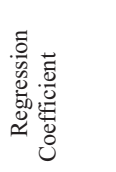 & 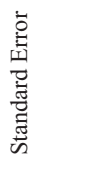 & 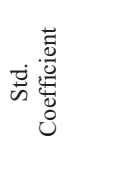 & 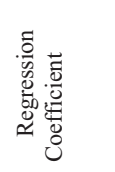 & 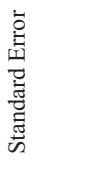 & 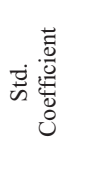 \\
\hline \multicolumn{13}{|l|}{ Control Variables } \\
\hline $\begin{array}{l}\text { Organizational } \\
\text { Age }\end{array}$ & 0,003 & 0,002 & 0,110 & 0,003 & 0,002 & 0,136 & 0,004 & 0,002 & $0,152 *$ & 0,003 & 0,002 & $0,148^{*}$ \\
\hline Industry & 0,221 & 0,121 & $0,193^{*}$ & 0,065 & 0,113 & 0,057 & 0,032 & 0,110 & 0,028 & 0,052 & 0,110 & 0,045 \\
\hline $\begin{array}{l}\text { Organizational } \\
\text { Size }\end{array}$ & 0,000 & 0,000 & 0,031 & 0,000 & 0 & $-0,014$ & 0,000 & 0,000 & $-0,012$ & 0,000 & 0,000 & $-0,018$ \\
\hline Export Income & $-0,003$ & 0,002 & $-0,121$ & $-0,003$ & 0,002 & $-0,111$ & $-0,003$ & 0,002 & $-0,117$ & $-0,002$ & 0,002 & $-0,106$ \\
\hline \multicolumn{13}{|l|}{$\begin{array}{l}\text { Independent } \\
\text { Variables }\end{array}$} \\
\hline \multicolumn{13}{|l|}{$\begin{array}{l}\text { Learning } \\
\text { Orientation } \\
\text { Dimensions }\end{array}$} \\
\hline $\begin{array}{l}\text { Internally-focused } \\
\text { Learning }\end{array}$ & & & & 0,233 & 0,067 & $0,370^{* * *}$ & 0,243 & 0,069 & $0,386 * * *$ & 0,163 & 0,075 & $0,259 * *$ \\
\hline $\begin{array}{l}\text { Market-focused } \\
\text { Learning }\end{array}$ & & & & 0,113 & 0,104 & 0,110 & 0,125 & 0,105 & 0,122 & 0,057 & 0,105 & 0,055 \\
\hline $\begin{array}{l}\text { Relationally- } \\
\text { focused Learning }\end{array}$ & & & & 0,081 & 0,095 & 0,085 & 0,073 & 0,097 & 0,076 & 0,067 & 0,095 & 0,070 \\
\hline \multicolumn{13}{|l|}{$\begin{array}{l}\text { Strategic Choice } \\
\text { Dimensions }\end{array}$} \\
\hline $\begin{array}{l}\text { Cost Leadership } \\
\text { Strategy }\end{array}$ & & & & & & & $-0,035$ & 0,083 & $-0,039$ & $-0,034$ & 0,081 & $-0,038$ \\
\hline Focus Strategy & & & & & & & $-0,140$ & 0,048 & $-0,245 * *$ & $-0,128$ & 0,047 & $-0,225 * *$ \\
\hline $\begin{array}{l}\text { Differentiation } \\
\text { Strategy }\end{array}$ & & & & & & & 0,063 & 0,079 & 0,080 & 0,046 & 0,092 & 0,059 \\
\hline \multicolumn{13}{|l|}{$\begin{array}{l}\text { Innovativeness } \\
\text { Dimensions }\end{array}$} \\
\hline $\begin{array}{l}\text { Behavioral } \\
\text { Innovativeness }\end{array}$ & & & & & & & & & & 0,003 & 0,106 & 0,003 \\
\hline $\begin{array}{l}\text { Product } \\
\text { Innovativeness }\end{array}$ & & & & & & & & & & 0,190 & 0,062 & $0,290 * *$ \\
\hline $\begin{array}{l}\text { Technological } \\
\text { Innovativeness }\end{array}$ & & & & & & & & & & 0,027 & 0,066 & 0,042 \\
\hline \multicolumn{13}{|l|}{ Model Summary } \\
\hline Adjusted R Square & 0,017 & & & 0,213 & & & 0,265 & & & 0,265 & & \\
\hline R Square & 0,053 & & & 0,263 & & & 0,332 & & & 0,396 & & \\
\hline$\Delta$ in $R$ Square & 0,053 & & & 0,210 & & & 0,069 & & & 0,064 & & \\
\hline $\begin{array}{l}\text { F for } \Delta \text { in } R \\
\text { Square }\end{array}$ & 1,488 & & & $9,888^{* * *}$ & & & $3,462 * *$ & & & $3,476^{* *}$ & & \\
\hline F for $A N O V A$ & 1,488 & & & $5,300 * * *$ & & & $5,012 * * *$ & & & $4,941 * * *$ & & \\
\hline $\begin{array}{l}{ }^{*} \mathbf{p}<0,10 \\
* * p<0,05 \\
* * * p<0,01\end{array}$ & & & & & & & & & & & & \\
\hline
\end{tabular}

Note: Provided in the Table are the results of four sequential regression runs. Model 1 regresses Firm Performance against the control variables only, and the following models include learning orientation dimensions, strategic choice dimensions and innovativeness dimensions one after the other hierarchically.

Concerning the individual effects of learning orientation on firm performance (Table 6, Model 2), internally-focused learning $\left(\beta_{\mathrm{i}}=0,370 ; \mathrm{p}<0,01\right)$ has a positive impact on performance. Next, with the inclusion of strategic choice dimensions into the analysis (Table 6, Model 3), organizational age $\left(\beta_{\mathrm{i}}=0,152 ; \mathrm{p}<0,10\right)$ emerges as a factor that is positively related to firm performance meaning that as firms age increase, their performance gets better. Internally-focused learning $\left(\beta_{\mathrm{i}}=0,386 ; \mathrm{p}<0,01\right)$ is the only statistically significant dimension that is positively related to firm performance. Focus strategy $\left(\beta_{\mathrm{i}}=-0,245 ; \mathrm{p}<0,05\right)$ is negatively related factor to firm performance showing that as the firms choose focus strategy less, their performance increases. In the subsequent analysis including innovativeness dimensions (Table 6, Model 4), organizational age $\left(\beta_{\mathrm{i}}=0,148 ; \mathrm{p}<0,10\right)$ again has a positive relationship with firm performance whereas among organizational learning dimensions, only internally-focused learning $\left(\beta_{\mathrm{i}}=0,259 ; \mathrm{p}<0,05\right)$ is positively related to firm performance. Once more, focus strategy $\left(\beta_{\mathrm{i}}=-0,225\right.$; $\mathrm{p}<$ $0,05)$ is negatively related driver of firm performance. Lastly, product innovativeness $\left(\beta_{\mathrm{i}}=0,290 ; \mathrm{p}<0,05\right)$ is the only innovativeness dimension having a significant effect on firm performance such that higher levels of product innovativeness leads to higher firm performance.

Organizational innovativeness emerges as a partial mediator between learning orientation and performance. The internally-focused learning dimension's standardized regression coefficient decreases (from $\beta_{\mathrm{i}}=0,386 ; \mathrm{p}<0,01$ to $\left.\beta_{\mathrm{i}}=0,259 ; \mathrm{p}<0,05\right)$ when we introduced the innovativeness dimensions into the analysis (Table 6, Model 3 and 4). In terms of strategic choice and performance, innovativeness does not have a mediating effect as there is only a slight 
decrease in its standardized regression coefficient (from $\beta_{\mathrm{i}}$ $=-0,245 ; \mathrm{p}<0,05$ to $\beta_{\mathrm{i}}=-0,225 ; \mathrm{p}<0,05$ in Table 6 , Model 3 and 4$)$.

As for the control variables, service firms are more behaviorally innovative than production firms $\left(\beta_{i}=-0,199 ; p\right.$ $<0,01)$ whereas older firms $\left(\beta_{i}=-0,143 ; \mathrm{p}<0,05\right)$ are more behaviorally innovative, younger firms $\left(\beta_{\mathrm{i}}=-0,194 ; \mathrm{p}<\right.$ $0,05)$ are more technologically innovative and older firms $\left(\beta_{\mathrm{i}}=0,148 ; \mathrm{p}<0,10\right)$ are better performers than younger firms.

In summary, H1, is partially supported, since marketfocused learning is significant only for and product and behavioral innovativeness. For $\mathrm{H} 2$, the results indicate partial support as the proposed relationship is only true for product and technological innovativeness. $\mathrm{H} 3$ and $\mathrm{H} 4$ are not supported while $\mathrm{H} 5$ is partially supported since differentiation strategy only relates to behavioral innovativeness. H6 is not supported as focus strategy is not significant for any of the innovativeness dimensions. $\mathrm{H} 7$ is partially supported since only internally-focused learning is a significant driver for performance. H8 is not supported since only focus strategy has a significant negative effect on performance. H9 is partially supported as only product innovativeness is a significant factor for performance. Thus, the results indicate significant values for only some relationships. In particular, the significant relationships are between (a) market-focused learning and internally-focused learning with product innovativeness, (b) market-focused learning and behavioral innovativeness, (c) internallyfocused learning and technological innovativeness. Among the strategic choices, only differentiation has a positive relationship with behavioral innovativeness. As for performance, internally-focused learning was found to have a positive effect whereas, in contrast to that hypothesized, focus strategy appears to be negatively related with it. Moreover, a significant relationship exists between product innovativeness and performance.

\section{Discussion and implications}

As this study is conducted in an ambiguous environment where firms are less familiar to learning as an integral part of business life and indigenous innovation, we believe the outcomes are rather noteworthy. The results indicate a positive relationship between behavioral innovativeness only with market-focused learning and differentiation strategy which provides partial support for $\mathrm{H} 1$ and $\mathrm{H} 5$. Hence, we provide the following explanations: If a particular firm aspires to increase its level of behavioral innovativeness, this means that it is willing to create a culture of innovativeness. This requires a certain strategy for addressing the customers' needs as well as gaining competitive edge through acquiring market knowledge. Given this framework, the results might be traced back to 1984 when the markets were opened to foreign penetration. Before then, Turkey was a closed economy run by importsubstitution policies which led to low quality, higher costs and prices. Once the domestic rivalry became fierce, the
Turkish consumers could attain high quality, low priced and differentiated goods/services. This might be the underlying reason why only differentiation strategy emerged as a significant factor. Even if competition as a concept is somewhat new, it seems that firms have captured the importance of standing out among their competitors. On top of this, firms recently had an opportunity to observe how the Chinese supply was low priced, yet efficient. This model verifies firms are now advancing their competitive practices by trying to extract learning opportunities to differentiate themselves from their competitors.

Internally-focused learning and relationally-focused learning are even more novel for the Turkish market; as they have become a part of business practices around the 1990s. We also must consider the time it takes to invest in R\&D capabilities as well as to establish and nourish trusting external relationships. Conversely, even when the economy was a closed one, there were a few firms in the domestic market since the 1950s. Although their activities and supply capacity were limited, some of these firms were acquainted with taking an inquisitive attitude towards their competitors since then. Thus, firms are more accustomed to marketfocused learning at an earlier date when compared to internally-focused learning and relationally-focused learning. Thus, $\mathrm{H} 1$ is supported while $\mathrm{H} 2$ and $\mathrm{H} 3$ are not supported for behavioral innovativeness.

When product innovativeness is considered, the results indicate a positive relationship only with market-focused learning and internally-focused learning but not with any of the strategic choice dimensions. Also, internally-focused learning seems to have a higher impact on product innovativeness when compared with market-focused learning with respect to their standardized regression coefficients. Seeing partial support for H1, H2 and H5 and no support for $\mathrm{H} 4$ and $\mathrm{H} 6$, we submit the subsequent justifications: New product development requires both market knowledge and information generated from R\&D activities to assess the real-life applicability of and the potential demand for the idea. Obviously, relationallyfocused learning activities are always useful for new product development; nevertheless, it takes time to establish new relationships and/or evaluate whether such liaisons are healthy and trustworthy. The reason why relationallyfocused learning has not emerged as a significant relationship in this analysis, or why H3 is not supported, might either because the firms have not yet formed external relationships or their existing relations have little to offer in terms of new product development. Also, the firms might be inexperienced or at the early stages of external relationshipbuilding which verifies the perspectives of Bell (2007) and Pietrobelli and Rabellotti (2011).

As for the non-significance of strategic choice dimensions in product innovativeness, or the rejection of H4, H5 and H6, we would like to underscore that many emerging markets are still dominated by contract manufacturing activities including the Turkish one. Mainly, MNCs mainly penetrate into such markets to reap the advantages of lower labor costs. Further, many firms export goods produced through 
contract manufacturing, excluding their trademarks, resulting in lower profit margins. Inherently, contract manufacturing activities do not require any kind of strategy crafting for new product development; consistent with our results. Also, many of the service firms are usually the subsidiaries of MNCs that receive orders from the headquarters which involves just application, but not strategy crafting. As the significance of market-focused learning points out, the firms simply scan the marketplace to see which kind of services are in demand and adapt accordingly rather than coming up with customized strategies.

In terms of technological innovation, the results indicate a significant relationship between internally-focused learning and only technological innovativeness and there are no significant relationships with any of the strategic choice dimensions. As for the partial support for $\mathrm{H} 2$ and rejection of $\mathrm{H} 1$ and $\mathrm{H} 3$, we present the subsequent explanations: In Turkey, the government subsidizes technological investments and this lowers overall cost of production and this encourages the firms to make profits through lowering costs by only using imported equipment/software. Crafting original strategies and/or coming up with innovative ways of conducting business is usually triumphed by short-term thinking. Therefore, the firms possibly did not acquire technology within a framework of a particular strategy. Rather, they probably purchased what they perceived as the most up to date and accessible. As the large sum of technological capabilities are acquired from developed markets, there is rather partial understanding and competence to manage and employ recently acquired knowledge, and frequently fall short of creating their individual competitive advantages by means of effective innovation (Hitt et al., 2000). The imperative here is that, firms are yet to grasp the importance of designing tailored technology to fit their needs rather than automatically purchasing the latest technology without aligning it with their strategic aspirations.

Preferably, the technological capacity of a particular firm needs to fit the aptitude of the manpower that will be operating it. New technology requires sophisticated workforce who can understand its principles and potentially come up with novel applications. Instead, Turkish firms consume most of the working time by learning how to use the new technology together with foreign language and terminology challenges. The significance of internallyfocused learning has a very high probability of indicating to these comprehension activities which, again, verifies the perspectives of Bell (2007) and Pietrobelli and Rabellotti (2011).

Further, contract manufacturing activities usually utilize cheap labor for lowering costs which ultimately means high turnover rates. In such an environment, the workers are almost certainly under-motivated and lack the propensity to innovate. Besides, the ones who use the new technology one-on-one are those who usually come up with innovative ways of doing things. These employees are middle-level technicians are undervalued in the Turkish business milieu.
As they receive on-the-job training and have more practical knowledge, they have a high probability to be innovative. Unfortunately, they do not have signing power in the hierarchy which deprives them from their abilities to provide an official input to innovative idea generation processes. These employees need to be on top of the technology they are using so that novel ideas can transpire in their minds but it seems not to be the case at the moment. This highlights that firms only learn internally, and hence; market-focused and relationally-focused learning do not come out as significant dimensions for technological innovation.

Moreover, as a general practice in Turkey, engineers are employed as both experts and managers in order to reduce costs emanating from salaries. Alas, these engineers are usually the only employees that grasp the principles of fully utilizing new technology. Ideally, they are the ones who should be teaching the use of new technology to lower level employees as well as coming up with innovative ideas. Considering the time-consuming and high-stakes managerial roles, the engineers usually end up pursuing their executive activities instead of coming up with innovative ideas. Hence, the new technology in firms is not used up to its potential and this gives way to inefficiency in the long-run.

Lastly, for firm performance, internally-focused learning and product innovativeness have significant relationships it whereas none of the strategic choice dimensions were positively related to it. As for this interesting outcome and partial support for $\mathrm{H} 7$ and $\mathrm{H} 9$ and rejection of $\mathrm{H} 8$, we provide the following reasons: The imbalanced income distribution in Turkey leads to different consumption styles and firms naturally take advantage of this situation. The high income group usually looks for very specific and customized goods/services and many firms opt for providing goods/services that exactly fit these needs. This mostly means product differentiation, as is reflected in the findings. Alternatively, the low income group is looking for technological goods and/or services that can be shown-off even if these goods/services might be beyond their means. In turn, firms aim to become more appealing by providing products/services that are designed specifically for lowincome consumers. Also, it is apparent that firms seem to perform better with differentiated goods/services over niche goods/services as the negative relationship between focus strategy and performance exhibits. From this point of view, it is only plausible for the firms to secure continuous inflow of customers by product innovativeness which is created via intensifying internal $R \& D$ activities.

To sum up, the Turkish market, as a typical representation of emerging markets, seems to have conquered basic obstacles towards economic stability as exhibited in World Bank figures in today's highly competitive and dynamic business milieu. The findings depict that the firms have started to appreciate the importance of organized learning activities and having a concrete strategy on elevating their innovativeness and performance levels. Still, there are significant effects for only a few of the proposed relationships. This outcome illustrates that firms are on the 
verge of creating sophisticated strategies and learning practices that will precisely address the demands of the local market, global competition and consumers.

\section{Future research directions and limitations}

The first limitation is the small sample size and thus, the study needs to be replicated with larger and more heterogeneous samples and in other emerging markets, to generalize the findings. Despite our rationale, the 3-year performance measurement might be considered as one that is short-term oriented. Even if the nature of innovativeness and learning is dynamic and continuous (Jean \& Sinkovics, 2010), we conducted the empirical analysis with crosssectional data. In effect, some outcomes could be the result of such data and might alter in a case where a longer term indicators and longitudinal data are employed. Another limitation may be the findings of the factor analysis. Unlike prior research, process and strategic innovativeness did not emerge as innovativeness dimensions although some of the technological innovativeness items fell under strategic innovativeness. We attribute this outcome to the complex nature of innovativeness dimensions coupled with the concept of strategy crafting in emerging nations. Although these economies possess several dynamics of advanced economies, some of the referred concepts might not be wellestablished in the perceptions and practices of the market players. Further, future research must examine how culture relates to the institutional context to shape the advantages afforded by organizational learning. Also, a finer-grained classification of industry types should be used so that industry-level institutional forces can be discerned more easily (Lu, Tsang \& Peng, 2008). Finally, this model should also be applied to MNCs and SMEs and the results should be compared and contrasted.

\section{Conclusion}

When faced with fierce competition, firms have to find ways to survive in the highly demanding marketplace. This research explores various aspects of innovativeness, learning orientation, strategic choice and performance of the firms in Turkey through world field literature and tested methods. The results reveal that dimensions of learning orientation and strategic choice associates with innovativeness and overall firm performance through different paths. Internallyfocused learning is related to product innovativeness, technological innovativeness and overall firm performance. Market-focused learning emerges as a determining factor on behavioral innovativeness and product innovativeness. Differentiation strategy plays an influential part on behavioral innovativeness. Most strikingly, product innovativeness is a significant factor in determining overall firm performance. These findings highlight the interplay between strategy and innovation as they jointly yield superior firm performance, particularly in emerging nations where the rules of the game are probably much different from those in developed economies.
Thus, managers who are already striving to survive in such a milieu and those who wish to come in to the emerging markets need to be aware of the realities of the conditions. We believe that these finding may help them, as Lu et al. (2008) put it, to devise interesting and novel managerial practices that will fit their specific needs. As time goes by, managers in emerging nations will learn considerably from these studies and find occasions to introduce their own rules into the global competition game. However, until then, we believe that in the fast-paced, highly unpredictable market atmosphere of emerging markets, managers can make use of these findings to their advantage in terms of elevating their firms' innovativeness and performance levels.

\section{References}

Allen, R.S. \& Helms, M.M. 2006. 'Linking strategic practices and organizational performance to Porter's generic strategies', Business Process Management Journal, 12(4): $433-454$.

Atuahene-Gima, K. 1993. 'Determinants of technology licensing intentions: An empirical analysis of Australian engineering firms', Journal of Product Innovation Management, 10(3): 230- 40 .

Aulakh, P.S. \& Kotabe, M. 2008. 'Institutional changes and organizational transformation in developing economies', Journal of International Management, 14(3): 209-216.

Baker, W.E. \& Sinkula, J.M. 1999. 'The synergistic effect of market orientation and learning orientation on organizational performance', Journal of Academy of Marketing Science, 27(4): 411-27.

Baker, W.E. \& Sinkula, J.M. 2002. 'Market orientation, learning orientation and product innovation: Delving into the organization's black box', Journal of Market-focused Management, 5(1): 5-23.

Baker, W.E. \& Sinkula, J.M. 2009. 'The complementary effects of market orientation and entrepreneurial orientation on profitability in small firms', Journal of Small Business Management, 47(4): 443 - 464.

Bell, M. 2007. Technological learning and the development of production and innovative capacities in the industry and infrastructure sectors of the least developed countries: What role for ODA? Background Paper No. 10 for The Least Developed Countries Report. Geneva: UNCTAD.

Blumentritt, T. \& Danis, W.M. 2006. 'Business strategy types and innovative practices', Journal of Managerial Issues, 18(2): 274 - 292.

Bruton, G.D., Dess, G,G. \& Janney, J.J. 2007. 'Knowledge management in technology-focused firms in emerging economies: Caveats on capabilities, networks and real options', Asia Pacific Journal of Management, 24: 115 130. 
Bush, R.J. \& Sinclair, S.A. 1992. 'Changing strategies in mature industries: A case study', The Journal of Business \& Industrial Marketing, 7(4): 63-72.

Calantone, R.J., Cavusgil, S.T. \& Zhao, Y. 2002. 'Learning orientation, firm innovation capability, and firm performance', Industrial Marketing Management, 31(6): 515-524.

Cohen, W.M. \& Levinthal, D.A. 1990. 'Absorptive capacity: A new perspective on learning and innovation', Administrative Science Quarterly, 35(1): 128-152.

Cooper, R.G. 2000. 'New product performance: What distinguishes The Star products', Australian Journal of Management, 25 (1): 17-45.

Danis, W.M., Chiaburu, D.S. \& Lyles, M.A. 2010. 'The impact of managerial networking intensity and market-based strategies on firm growth during institutional upheaval: A study of small and medium-sized enterprises in a transition economy', Journal of International Business Studies, 41: $287-307$.

Ferraresi, A.A., Quandt, C.O., Dos Santos, S.A. \& Frega, J.R. 2012. 'Knowledge management and strategic orientation: Leveraging innovativeness and performance', Journal of Knowledge Management, 16(5): 688 - 701.

Frank, H., Kessler, A., Mitterer, G., \& Weismeier-Sammer, D. 2012. 'Learning orientation of SMEs and its impact on firm performance', Journal of Marketing Development and Competitiveness, 6(3):29-41.

Freeman, C. 1978. The economics of industrial innovation, London: Penguin.

Garcia, R. \& Calantone, R. 2002. 'A critical look at technological innovation typology and innovativeness terminology: A literature review', The Journal of Product Innovation Management, 19: 110 - 132.

Grant, R.M. 2008. Contemporary strategy analysis. $7^{\text {th }}$ Edition. Maden, MA: Blackwell Publishing.

Hanvanich, S., Sivakumar, K. \& Hult, G.T.M. 2006. 'The relationship of learning and memory with organizational performance: The moderating role of turbulence', Journal of the Academy of Marketing Science, 34(1): 600-612.

Hitt, M.A., Dacin, M.T., Levitas, E., Arregle, J.L. \& Borza, A. 2000. 'Partner selection in emerging and developed market contexts: Resource-based and organizational learning perspectives', Academy of Management. Journal, 43(3): $449-467$.

Hoskisson, R.E., Eden, L., Lau, C.M. \& Wright, M. 2000. 'Strategy in emerging economies', Academy of Management Journal, 43: 249 - 267.
Hsu, S.H. 2007. 'Human capital, organizational learning, network resources and organizational innovativeness', Total Quality Management, 18(9): 983-998.

Hult, G.T.M., Hurley, R.F. \& Knight, G.A. 2004. 'Innovativeness: Its antecedents and impact on business performance', Industrial Marketing Management, 33(5): $429-438$.

Jaworski, B.J. \& Kohli, A.K. 1993. 'Market orientation: Antecedents and consequences', Journal of Marketing, 57(3): $53-70$.

Jean, R.B. \& Sinkovics, R.R. 2010 'Relationship learning and performance enhancement via advanced information technology: The case of Taiwanese Dragon electronics firms', International Marketing Review, 27(2): 200 - 222.

Lei, D., Slocum, J.W. \& Pitts, R.A. 1999. 'Designing organizations for competitive advantage: The power of unlearning and learning, Organizational Dynamics, 37(3): 24-38.

Li, Y., Zhang, C., Liu, Y. \& Li, M. 2010. 'Organizational learning, internal control mechanisms, and indigenous innovation: The evidence from China', IEEE Transactions on Engineering Management, 57(1): 63 - 77.

Lin, C.H., Peng, C.H. \& Kao, D.T. 2008. 'The innovativeness effect of market orientation and learning orientation on business performance', International Journal of Manpower, 29(8): 752 - 772.

López, S.P., Peón, J.M.M. \& Ordés, C.J.V. 2005. 'Organizational learning as a determining factor in business performance', The Learning Organization, 12(3): 227 - 245.

Lu, Y., Tsang, E.W.K. \& Peng, M.W. 2008. 'Knowledge management and innovation strategy in the Asia Pacific: Toward an institution-based view', Asia Pacific Journal of Management, 25(3): 361 - 374.

Man, M.K.M. \& Wafa, S.A. 2008. 'The relationship between innovativeness, strategy types, environment and the export performance of small and medium-sized enterprises (SMEs) of Malaysian manufacturing sector', The Business Review, 13(2): 145 - 154.

Miles, R.E. \& Snow, C.C. 1978. Organizational strategy, structure and process. New York: McGraw Hill.

Miller, D. 1986. 'Configurations of strategy and structure: Towards a synthesis', Strategic Management Journal, 7(3): 233-249.

Miller, D. \& Friesen, P.H. 1986. 'Porter's (1980) generic strategies and performance: An empirical examination with American data. Part I: Testing Porter', Organization Studies, 7(1): 37-55. 
Nunnally, J.C. 1978. Psychometric theory. New York: McGraw-Hill Book Firm.

Panayides, P.M. 2003. 'Competitive strategies and organizational performance in ship management', Maritime Policy and Management, 30(2): 123-140.

Pietrobelli, C. \& Rabellotti, R. 2011. 'Global value chains meet innovation systems: Are there learning opportunities for developing countries? ', World Development, 39(7): $1261-1269$.

Porter, M.E. 1980. Competitive strategy. New York: The Free Press.

Porter, M.E. 1985. Competitive advantage: Creating and sustaining superior performance. New York: The Free Press.

Powers, T.L. \& Hahn, W. 2004. 'Critical competitive methods, generic strategies, and firm performance', The International Journal of Bank Marketing, 22(1): 43-64.

Rhee, J., Taekyung, P. \& Lee, D.H. 2010. 'Drivers of innovativeness and performance for innovative SMEs in South Korea: Mediation of learning orientation', Technovation, 30(1): $65-75$.

Rothwell, R. 1992. 'Successful industrial innovation: Critical factors for the 1990s', $R \& D$ Management, 22(3): 221- 240 .

Slater, S.F. \& Narver, J.C. 1995. 'Market orientation and the learning organization', Journal of Marketing, 59(3): 63-74.

Thompson Jr., A.A., Strickland III, A.J. \& Gamble, J.E. 2005. Crafting and executing strategy: The quest for competitive advantage, concepts and cases, $14^{\text {th }}$ Edition. New York, NY: McGraw-Hill.

Wang, C.L. \& Ahmed, P.K. 2004. 'The development and validation of the organizational innovativeness construct using confirmatory factor analysis', European Journal of Innovation Management, 7(4): 303-313.

Warner, A.M. \& Cornelius, P.K. 2002. The European competitiveness and transition report: Ratings of accession progress, competitiveness, and economic restructuring of European and transition economies. New York: Oxford University Press

Weerawardena, J. 2003. 'Exploring the role of market learning capability in competitive strategy', European Journal of Marketing, 37(3/4): 407-429.

Weerawardena, J., O’Cass, A. \& Julian, C. 2006. 'Does industry matter? Examining the role of industry structure and organizational learning in innovation and brand performance', Journal of Business Research, 59(1): 37-45.
White, R.E. 1986. 'Generic business strategies, organizational context and performance: An empirical investigation', Strategic Management Journal, 7(3): $217-$ 231.

World Bank. 2012. 'The World Bank Data. Web. 04 December 2012'. [online] URL:http://data.worldbank.org/country/turkey.

Wright, M., Filatotchev, I., Hoskisson, R.E., \& Peng, M.W. 2005. 'Strategy research in emerging economies: Challenging the conventional wisdom', Journal of Management Studies, 42(1): 1-33.

Yamin, S., Gunasekaran, A. \& Mavondo, F.T. 1999. 'Relationship between generic strategies, competitive advantage and organizational performance: An empirical analysis', Technovation, 19: 507-518.

\section{Appendix A}

\section{Full list of items in the questionnaire}

\begin{tabular}{|c|}
\hline Constructs \\
\hline Organizational Innovativeness \\
\hline $\begin{array}{l}\text { In new product and service introductions, our company is often first-to- } \\
\text { market. }\end{array}$ \\
\hline $\begin{array}{l}\text { Our new products and services are often perceived as very novel by } \\
\text { customers. }\end{array}$ \\
\hline $\begin{array}{l}\text { Our new products and services are only minor changes from our } \\
\text { previous products and services. }\end{array}$ \\
\hline $\begin{array}{l}\text { New products and services in our company often take us up against } \\
\text { new competitors. }\end{array}$ \\
\hline $\begin{array}{l}\text { In comparison with our competitors, our company has introduced more } \\
\text { innovative products and services in during the past five years. }\end{array}$ \\
\hline $\begin{array}{l}\text { In comparison with our competitors, our company is faster in bringing } \\
\text { new products or services into the market. }\end{array}$ \\
\hline $\begin{array}{l}\text { In comparison with our competitors, our company has a lower success } \\
\text { rate in new products and services launch. }\end{array}$ \\
\hline $\begin{array}{l}\text { In comparison with our competitors, our products most recent } \\
\text { marketing program is revolutionary in the market. }\end{array}$ \\
\hline $\begin{array}{l}\text { Our company's most recent new product introduction required a new } \\
\text { form of advertising and promotion, different from that used for our } \\
\text { existing products. }\end{array}$ \\
\hline $\begin{array}{l}\text { In new product and service introductions, our company is often at the } \\
\text { cutting edge of technology. }\end{array}$ \\
\hline The technology of our main machinery in use is very up-to-date. \\
\hline $\begin{array}{l}\text { Our future investments in new machinery and equipment are } \\
\text { significant compared with our annual turnover. }\end{array}$ \\
\hline $\begin{array}{l}\text { In comparison with our competitors, we are late in adoption of } \\
\text { technological innovations. }\end{array}$ \\
\hline $\begin{array}{l}\text { Our firm's R\&D or product development resources are not adequate to } \\
\text { handle the development need of new products and services. }\end{array}$ \\
\hline $\begin{array}{l}\text { The nature of the manufacturing process in our company is new } \\
\text { compared with that of our main competitors. }\end{array}$ \\
\hline We are constantly improving our business processes. \\
\hline $\begin{array}{l}\text { Our company changes production methods at a great speed in } \\
\text { comparison with our competitors. }\end{array}$ \\
\hline $\begin{array}{l}\text { Our future investments in new methods of production are significant } \\
\text { compared with our annual turnover. }\end{array}$ \\
\hline $\begin{array}{l}\text { During the past five years, our company has developed many new } \\
\text { management approaches. }\end{array}$ \\
\hline $\begin{array}{l}\text { We get a lot of support from managers if we want to try new ways of } \\
\text { doing things. }\end{array}$ \\
\hline
\end{tabular}


Key executives of the firm are willing to take risks to seize and explore "chancy" growth opportunities.

Management actively responds to the adoption of "new ways of doing things" by main competitors.

Senior executives constantly seek unusual, novel solutions to problems via the use of "idea men".

In our company, we tolerate individuals who do things in a different

way.

We are willing to try new ways of doing things and seek unusual, novel solutions.

We encourage people to think and behave in original and novel ways.

When we see new ways of doing things, we are last at adopting them.

When we cannot solve a problem using conventional methods, we

improvise on new methods.

\section{Learning Orientation}

We use networks and links to acquire knowledge.

We undertake internal R\&D.

We collect information about markets.

We search for innovative ideas through market information.

We have knowledge about market segments.

We internally share knowledge generated through internal R\&D.

We review past unsuccessful R\&D.

We jointly work with other organizations to acquire knowledge.

We utilize networks to acquire knowledge.

We have knowledge about our competitors.

The skill level of staff involved in R\&D is high.

We allocate a considerable amount to $\mathrm{R} \& \mathrm{D}$.

We search for innovations through external networks.

We share knowledge acquired through networks within the firm.

We share information with employees.

We use customer and competitor information in innovations.

We review past unsuccessful endeavors.

Our R\&D knowledge is used in innovations.

We use knowledge generated externally in innovations.

We review past unsuccessful program for external knowledge.

We learn from market changes that enable us to successfully compete.

We have capacity to acquire knowledge through R\&D.

We have capability to acquire knowledge externally.

\section{Strategic Choice}

We minimize our purchasing costs.

We minimize our production costs.

We employ talented professionals and experts.

We base our incentives on meeting quality improvement goals.

We focus on segments of the market for marketing strategies.

We serve limited number of customers belonging to specific segments rather than competing with rivals in the full market.

We minimize our marketing costs.

We have strict cost controls for every business activity.

We minimize unused capacity.

We continuously improve our personnel.

We maximize product and service quality.

We establish a trustworthy brand image in the eyes of the customers.

We target the niche market rather than the large market.

We undertake extensive market research in a specific niche market.

We allow the personnel to test and we tolerate them to fail.

We evaluate the cost of failures not as a loss but as an opportunity to

learn.

We minimize costs of waster, repair, etc.

In our company, we have frequent preparation of detailed control reports.

We have a clear market position.

We dominate the distribution channels.

We allocate a large share in the budget for the marketing activities.

We engage in a tough combat of quality with the competitors.

Total sales growth

Firm Performance

Market share

Customer satisfaction
Customer loyalty

Identifying and understanding the customer

Communications through advertising and sales force

Effective and low-cost distribution practices

Effective and flexible pricing practices

Brand and product recognition among customers

Return on investments

Product / service quality

New product development

Employee satisfaction

Overall performance 